\title{
Marx contra o Estado
}

Marx against the State

Para Sebastião Neto e Elias Stein

O que os textos de Marx, de seus artigos de 1842 até a Crítica do Programa de Gotha, de 1875, nos dizem sobre sua concepção da política? Existe um pensamento político marxiano? Se Marx não legou "tratados de teoria política como Locke, nem sistemas de filosofia do Estado como Hegel” (Löwy, 2009, p. 7), insistiu em alguns pontos-chave, tais como a opressão estatal, sua articulação com a exploração capitalista e os elos entre revolução, democracia e comunismo. Isso pode ser percebido nos seus mais variados escritos, nas polêmicas com Hegel e os jovens hegelianos, nos textos sobre os levantes revolucionários (1848, Comuna de Paris), nos debates do movimento operário e nas obras sobre a economia política. Um pensamento político múltiplo, levando a distantes e díspares compreensões, desde Bakunin e certos anarquistas, que o taxaram de "socialismo de Estado", até Hans Kelsen, que considerava sua teoria política - assim como a de Engels - como um "puro anarquismo" (Dayan-Herzbrun, 1990, p. 156), enquanto certos marxistas a resumiam à ditadura do proletariado.

Norberto Bobbio (1991 [1979]), em seu artigo "Existe uma doutrina marxista do Estado?", procurou e não encontrou uma teoria do Estado em Marx. Estava certo ao afirmar tal inexistência? Michael Hardt e Antonio Negri, em Trabalho de Dioniso, contrapõem tal perspectiva pensando não num

\footnotetext{
É professor de Relações Internacionais do Centro Universitário Fundação Santo André (São Paulo, SP, Brasil) e diretor de projetos da Fundação Frierich Ebert. E-mail: jtible@gmail.com 
exercício de filologia marxista, mas situando Marx numa "crítica prática ao direito e às instituições do Estado a partir do ponto de vista do movimento revolucionário" (Hardt e Negri, 2004, p. 11). Toma forma, assim, não exatamente uma teoria marxista do Estado, mas um questionamento radical do estatal. Desse modo, "o ponto de partida para uma crítica marxista do Estado é expresso em termos negativos” (Hardt e Negri, 2004, p. 14), lembrando a definição de comunismo presente em A ideologia alemã.

Além disso, trata-se de "um pensamento em movimento, que parte das lutas reais dos oprimidos e que se enriquece com suas experiências revolucionárias" (Löwy, 2009, p. 7, grifo no original), ligando-nos à visão de Marx aqui trabalhada, privilegiando os vínculos entre sua teoria e as lutas. Ao apreender o pensamento político de Marx acerca do Estado, deve-se não esquecer que “o conteúdo de seu pensamento não é separável de seus deslocamentos. É por isso que não se pode, para estudá-lo, reconstituir abstratamente o seu sistema. É preciso traçar a sua evolução, com suas rupturas e bifurcações" (Balibar, 1995, p. 12). Por isso, a proposta de seguir suas trajetórias nos numerosos e diferentes escritos (livros, artigos, cartas, comentários à margem), tomando como fio condutor o projeto marxiano de uma outra política no sentido da superação da sua dimensão estatal.

\section{Manifesto político de 1843-1844}

Os anos iniciais da década de 1840 configuram-se como um período decisivo no qual Marx define os pilares do seu pensamento político na forma de um movimento contra o Estado. Em um dos seus primeiros trabalhos sobre os "interesses materiais" (Marx, 2009b [1859], p. 487), a problemática estatal vem à tona. $\mathrm{O}$ autor acompanha, em diversos artigos na Gazeta Renana, a discussão na Dieta (Assembleia) para definir se a prática tradicional de colheita de lenha por parte dos pobres configurava-se como roubo ou não. Frente à disputa entre duas concepções de propriedade - privada versus costumes - o Estado joga um papel determinante.

No âmbito de seu engajamento "prático-teórico" nesse jornal, Marx polemiza com Hegel. Seu sistema filosófico "faz sombra a todo movimento intelectual. Cada tomada de posição" o é "frente ao "mito de Hegel”" (Lascoumes e Zander, 1984a, p. 11). Esses artigos representam o início do seu questionamento da concepção hegeliana do direito e do Estado. De um lado, Marx desenvolve uma percepção das contradições internas do Estado; de 
outro, esboça uma perspectiva diferente, indo além da "negatividade abstrata que a sociedade civil mantém para Hegel em sua relação com o Estado" (Lascoumes e Zander, 1984b, p. 265), ao perceber um papel positivo - isto é, de criação - na sociedade.

Partindo de um ideal estatal, Marx decepciona-se com sua ação concreta. A conclusão dessas matérias jornalísticas, irônica, o deixa bastante claro: “[A] Dieta cumpriu perfeitamente sua missão. De acordo com sua vocação, representou um interesse particular determinado e o tratou como seu objetivo final” (Marx, 1984 [1842], p. 167). O jornalista-filósofo critica essa elevação do interesse particular dos proprietários de florestas a interesse geral. E questiona o Estado prussiano por posicionar-se do lado do interesse privado, estabelecendo uma contradição com sua suposta encarnação do interesse geral. Conforme colocado por Marx alguns meses antes, "o Estado que não é a realização da liberdade racional é um mau Estado” (Marx, 1982 [1842], p. 218), defendendo o autor a capacidade estatal de mediação e sua tarefa de, pela capacidade de estar uma esfera acima daquela onde os conflitos aparecem, fazer prevalecer o ponto de vista racional da totalidade. Eis a solução política (do Estado).

Marx esboça, entretanto, um deslocamento inicial dessa apreensão do Estado como organizador, apontando um outro caminho - e fonte - para que a lei alcance o interesse geral da comunidade política. Nesse sentido, "estes costumes próprios à classe pobre são regidos assim por um sentido instintivo do direito; sua raiz é positiva e legítima, e (...) não encontrou ainda uma posição adequada no seio da organização consciente do Estado" (Marx, 1984 [1842], p. 142). O autor distingue direito dos proprietários e direito à existência e, nesse âmbito, o Estado, para garantir sua universalidade, deve reagir contra certos interesses privados e incorporar outros.

É sintomático que esse engajamento inicial jornalístico-político de Marx finde-se "pelo Estado: não o 'verdadeiro Estado' ou o Estado ideal-racional hegeliano, mas pelo bem real Estado de Frederico Guilherme IV" (Draper, 1977, p. 75), com a supressão da Gazeta Renana. Pode-se dizer que Marx sentiu na pele o Estado concreto. A partir dessa interrupção, o autor se recolhe para um período intenso de estudos, de maio a outubro de 1843, no qual aprofunda seus pensamentos acerca do político e do estatal. Seus trabalhos preenchem cinco cadernos de mais de 250 páginas e "testemunham do esforço tentado por Marx (...) para iniciar-se na história das revoluções 
francesa, inglesa e americana e suas consequências" (Rubel, 1994, p. xxxiv), acompanhadas pela leitura dos clássicos da política, tais como Rousseau, Montesquieu, Maquiavel e Espinosa. De acordo com Isaiah Berlin (1991 [1978], p. 85), os anos de 1843 a 1845 foram os anos decisivos de sua vida, sendo que é em Paris - e graças ao contato com o movimento operário - que seu amadurecimento intelectual conclui-se. Tal período tem início com o Manuscrito de Kreuznach, primeira parte do seu manifesto político.

Neste texto de 1843, Marx, como o colocou dezesseis anos depois, "para resolver as dúvidas que o tomavam", empreendeu uma "revisão crítica da filosofia do direito de Hegel” (Marx, 2009b [1859], p. 487). Trata-se de um texto-chave para a compreensão do pensamento político marxiano e toma a forma de uma leitura de Princípios da filosofia do direito de Hegel (1989 [1821]), acompanhada de reflexões e comentários. Esse manuscrito permaneceu ignorado pelas primeiras gerações marxistas, sendo publicado somente em 1927-1928 por Riazanov na União Soviética e por Landshut e Mayer na Alemanha.

Essa Crítica constitui um texto inaugural. Não por acaso, Marx o menciona e o destaca no Posfácio à segunda edição alemã de O capital (1873), ao afirmar que "criticou o lado mistificador da dialética hegeliana há quase trinta anos, numa época em que ela ainda estava na moda" (Marx, 2006c [1873], p. 17), isto é, no ano de 1843. De acordo com Della Volpe, além de sua crítica da lógica hegeliana e das “mistificações’ da dialética a priori, idealista", esse texto "enuncia as premissas mais gerais de um novo método" (Della Volpe, 1974, p. 200). Que formas toma essa crítica de Hegel? O que é o Estado para Hegel?

Em Princípios da filosofia do direito, Hegel (\$261) diz que

em face das esferas do direito privado e do bem privado, da família e da sociedade civil, o Estado é, de um lado, uma necessidade externa e sua potência superior, a cuja natureza as leis daquelas esferas, bem como seus interesses, encontram-se subordinados e da qual são dependentes; porém, de outro lado, é o Estado seu fim imanente e tem sua força na unidade de seu fim último geral e no interesse geral e no interesse particular dos indivíduos, na medida em que tais indivíduos têm deveres perante ele assim como, ao mesmo tempo, têm direitos (Marx, 2005a [1843], p. 27, grifos no original).

Para Marx, tal definição hegeliana "nos ensina que a liberdade concreta consiste na identidade (normativa, dúplice) do sistema de interesses parti- 
culares (da família e da sociedade civil) com o sistema do interesse geral (do Estado)" (Marx, 2005a [1843], p. 27). Ao se expressar em termos de "necessidade externa”, Hegel subordina, em caso de colisão, as leis da família e da sociedade civil em favor das do Estado, tendo em vista que este representa a "relação essencial" e uma "potência superior". Ademais, continua Marx, "Hegel estabelece, aqui, uma antinomia sem solução. De um lado, necessidade externa; de outro, fim imanente". Deste modo, "a unidade do fim último geral do Estado e dos interesses particulares dos indivíduos deve consistir em que seus deveres para com o Estado e seus direitos em relação a ele sejam idênticos" (Marx, 2005a [1843], p. 28, grifos no original).

Dito isso, Marx concentra-se numa dupla fragilidade do texto - e da perspectiva filosófica - de Hegel, sua inversão e abstração. Isso consiste em fazer da Ideia, o sujeito, e do sujeito, predicado. Hegel parte da ideia abstrata e inverte, assim, produto e sujeito; "não desenvolve seu pensamento a partir do objeto, mas desenvolve o objeto segundo um pensamento previamente concebido na esfera abstrata da lógica", incorrendo em mistificações. Em outras palavras, “o movimento filosófico não é a lógica da coisa, mas a coisa da lógica. A lógica não serve à demonstração do Estado, mas o Estado serve à demonstração da lógica" (Marx, 2005a [1843], p. 36-39).

Ademais, Hegel aponta a contradição entre Estado e sociedade civil e trabalha sua resolução na forma soberana e monárquica. Segundo ele (\$275),

o poder soberano contém em si mesmo os três momentos da totalidade, a universalidade, da constituição e das leis, a deliberação como relação particular com o universal e o momento da decisão última como a autodeterminação a qual tudo o mais retorna e de onde toma o começo da realidade. Este absoluto autodeterminar-se constitui o princípio distintivo do poder soberano como tal, que é o primeiro a ser desenvolvido (Marx, 2005a [1843], p. 39, grifos no original).

De acordo com Marx (2005a [1843], p. 39), Hegel indica que no poder soberano estatal se situa a "universalidade da constituição e das leis". Tal mistificação, para Marx, poderia ser evitada caso Hegel se baseasse nos sujeitos reais e não numa subjetivização do Estado. O filósofo procede, ainda, a uma "reconciliação com a realidade", ao transformar "todos os atributos

Lembrando a conhecida formulação de Hegel no prefácio:"[O] que é racional, é o que é real; e o que é real, é o que é racional" (Hegel, 1821, p. 73). A interpretação desse trecho dividia os hegelianos entre "jovens" e "velhos" e entre "esquerda" e "direita". 
do monarca constitucional na Europa atual em autodeterminações absolutas da vontade. Ele não diz: a vontade do monarca é a decisão última, mas a decisão última da vontade é... o monarca” (Marx, 2005a [1843], p. 45), sendo a primeira frase empírica e a segunda, metafísica.

Na visão hegeliana, "o Estado como soberano deve ser Uno, Um indivíduo, deve possuir individualidade. O Estado é Uno 'não somente' nessa individualidade; a individualidade é apenas o momento natural de sua unidade, a determinação natural do Estado". Para Marx, o filósofo deveria perceber que "o Uno tem verdade somente como muitos Unos". Ao invés disso, "Hegel conclui: A personalidade do Estado é real somente como uma pessoa, o monarca" (Marx, 2005a [1843], p. 45-47). Desse modo, "Hegel generaliza o Estado histórico de uma época bem determinada para fazer dele uma essência geral" e "se proíbe de nos explicar na sua estrutura e sua gênese (históricas) e então de criticar (de onde compreendemos facilmente sua famosa exaltação ou idealização da monarquia 'constitucional' prussiana semi-feudal de 1820!)" (Della Volpe, 1974, p. 206, grifos no original).

Hegel trata, igualmente, do papel-chave da burocracia. Essa é a "consciência do Estado", a "vontade do Estado", a "potência do Estado", tendo assim "a posse da essência do Estado, da essência espiritual da sociedade; essa é sua propriedade privada”. Ligando a distinção Estado/sociedade civil ao papel da burocracia, Marx defende que "Hegel parte de uma oposição irreal e a conduz somente a uma identidade imaginária, ela mesma, em verdade, uma identidade contraditória. Uma tal identidade é a burocracia" (Marx, 2005a [1843], p. 66-68). Dessa forma, os "delegados do poder governamental" constituem uma verdadeira representação no Estado e, frente à oposição entre Estado e sociedade civil, a chave situa-se na mediação desses delegados, gestores do Estado. Demonstrando a que ponto levava a oposição entre sociedade civil e Estado em Hegel, Marx ironiza que “a 'polícia', os 'tribunais' e a 'administração' não são deputados da própria sociedade civil, que neles e por meio deles administra o seu próprio interesse universal, mas sim delegados do Estado para administrar o Estado contra a sociedade civil" (Marx, 2005a [1843], p. 66-68).

Marx questiona, assim, a universalidade do estamento universal de Hegel, em que este situa a solução do enigma político. Essa mediação - da burocracia - acaba sendo "uma proteção contra a multidão, a turba. Os estamentos representam o Estado em uma sociedade que não é um Estado. O Estado é uma mera representação" (Marx, 2005a [1843], p. 87). Em suma, Hegel 
pressupôs a separação da sociedade civil e do Estado político (uma situação moderna) e a desenvolveu como momento necessário da Ideia, como verdade absoluta racional. Apresentou o Estado político na sua forma moderna da separação dos diferentes poderes. Ao Estado real e agente, ele deu a burocracia como seu corpo e colocou esta, como o espírito que sabe, acima do materialismo da sociedade civil. Opôs o universal em si e para si existente do Estado aos interesses particulares e à necessidade da sociedade civil. Em uma palavra, ele expõe, por toda parte, o conflito entre sociedade civil e Estado (Marx, 2005a [1843], p. 91).

A tais abstrações e apreensões hegelianas, Marx propõe uma inversão. Assim, "o Estado é um abstractum. Somente o povo é concretum. E é notável que Hegel atribua sem hesitação uma qualidade viva ao abstractum, tal como a soberania, e só o faça com hesitação e reservas em relação ao concretum". Trata-se de uma ilusão compreender a soberania como absorvida no monarca; pensando em Hamlet, Marx coloca seu dilema político: "soberania do monarca ou do povo, eis a question", nessa oposição uma das duas sendo falsa. É nesse âmbito que Marx pensa a democracia. Esta, ao contrário da monarquia, na qual "uma parte determina o caráter do todo", pode ser "explicada a partir de si mesma", sendo "o gênero da constituição. A monarquia é uma espécie e, definitivamente, uma má espécie. A democracia é conteúdo e forma" (Marx, 2005a [1843], p. 48-49).

Marx chega, destarte, a um entendimento da democracia como autodeterminação do povo, sendo o momento do demos em seu conjunto. Se "na monarquia temos o povo da constituição; na democracia, a constituição do povo. A democracia é o enigma resolvido de todas as constituições". Nesse sentido, "do mesmo modo que a religião não cria o homem, mas o homem cria a religião, assim também não é a constituição que cria o povo, mas o povo a constituição". Trata-se, assim, de uma total inversão do paradigma hegeliano, pois "o homem não existe em razão da lei, mas a lei existe em razão do homem, é a existência humana, enquanto nas outras formas de Estado o homem é a existência legal. Tal é a diferença fundamental da democracia” (Marx, 2005a [1843], p. 50).

A democracia - e não um estamento burocrático ou um monarca - constitui "a verdadeira unidade do universal e do particular". Consequentemente, "os franceses modernos concluíram, daí, que na verdadeira democracia o Estado político desaparece. O que está correto", pois "na democracia, a constituição, a lei, o próprio Estado é apenas uma autodeterminação e um 
conteúdo particular do povo" (Marx, 2005a [1843], p. 50-51). Quem são esses franceses modernos? De acordo com Rubel (1994), foi a leitura de Considerant, Fourier, Proudhon, Saint-Simon, dentre outros, que influenciou decisivamente Marx.

A democracia, solução do enigma político, diferencia-se decisivamente das outras formas. No âmbito democrático, "o Estado abstrato deixou de ser o momento preponderante. A luta entre monarquia e república é, ela mesma, ainda, uma luta no interior do Estado abstrato. A república política é a democracia no interior da forma de Estado abstrata" (Marx, 2005a [1843], p. 51). Desse modo, "a democracia só existe na medida em que ela se levanta contra o Estado" (Abensour, 2004, p. 8, grifos no original). Uma distinção fundamental entre o político e o estatal faz-se sentir, pois - repetindo - "na verdadeira democracia o Estado político desaparece”. A exceção democrática situa-se precisamente no fato de a democracia não permitir uma "confusão mistificadora" entre parte e todo, entre Estado político e demos. Tal forma política "vai deixar o campo livre para a atividade instituidora do sujeito que é ele mesmo seu próprio fim" (Abensour, 2004, p. 110), ligando-se ao escrito anterior estudado, que começou a levar em conta a criatividade política do povo.

A "verdadeira democracia" vai além da abstração do Estado moderno sem negar a existência e necessidade de uma esfera política. É que Estado e política não obrigatoriamente acompanham-se mutuamente. O pensamento político marxiano abre nesse texto um ímpeto contra o Estado, tendo em vista que "mais a democracia aproxima-se de sua verdade (mas uma comunidade política atinge em algum momento sua verdade?), mais o Estado decresce, conhece um processo de desaparecimento" (Abensour, 2004, p. 146). Nesse sentido, Marx defende a "eleição ilimitada" como uma forma de a sociedade civil elevar-se "à existência política como sua verdadeira existência universal, essencial". O desaparecimento do Estado liga-se ao da sociedade civil, pois "com uma das partes separadas cai a outra, o seu contrário. A reforma eleitoral é, portanto, no interior do Estado político abstrato, a exigência de sua dissolução, mas igualmente da dissolução da sociedade civil" (Marx, 2005a [1843], p. 135). Na Inglaterra do século 17, "sociedade civil” é sinônimo de "sociedade política" (por exemplo, em John Locke). Para Rousseau, também. Hegel desloca o conceito do político ao econômico, ligando-o à sociedade civil burguesa. Nesse âmbito, "a fenda hegeliana entre a sociedade civil e o 
Estado não revelou outra fenda possível até esse momento despercebida, tanto o estatismo hegeliano a havia espontaneamente ocultado, a que existe entre a comunidade política e o Estado?" (Abensour, 2004, p. 15-16).

Ademais, a crítica marxiana de Hegel relaciona-se com a ideia de propriedade. Para ele, o único momento em que se realiza a identidade do universal e do particular é na pessoa do monarca; "mas se o príncipe é a pessoa abstrata, que tem o Estado em si, isto significa tão somente que a essência do Estado é a pessoa abstrata, a pessoa privada. Só no seu ápice ele exprime seu segredo" (Marx, 2005a [1843], p. 60). Disso decorre que “o príncipe é a única pessoa privada na qual se realiza a relação da pessoa privada em geral com o Estado" (Marx, 2005a [1843], p. 60). Nesse sentido, “a constituição política em seu ponto culminante é, portanto, a constituição da propriedade privada. A mais alta disposição política é a disposição da propriedade priva$d a$ ". As duas instâncias tornam-se inseparáveis: o Estado é o "próprio poder da propriedade privada" (Marx, 2005a [1843], p. 114-116). Dessa forma, "o verdadeiro fundamento da propriedade privada, a posse, é um fato, um fato inexplicável, não um direito" (Marx, 2005a [1843], p. 125), as determinações jurídicas garantindo a propriedade privada.

Forma-se nesse escrito, algo como um "princípio político", um fio condutor do pensamento político marxiano na forma do "contra o Estado". A partir de uma crise política e filosófica de Marx, ocorre uma substituição do sujeito político Estado por outro. Frente a Hegel e sua busca da essência, Marx contrapõe "a existência, segundo a realidade, em seu fundamento real, o homem real, o povo real, e posta como a obra própria deste último" (Marx, 2005a [1843], p. 50). Em suma, "uma verdadeira crítica da modernidade política, sob o signo da democracia" (Abensour, 2004, p. 42), a influência de Espinosa sendo decisiva ${ }^{2}$. Em sua lua de mel e retiro estudioso em Kreuznach encontramos um momento decisivo na trajetória intelectual de Marx. Essa Crítica (com sua Introdução) e a A questão judaica (junto com os Manuscritos parisienses e as Glosas) são parte "de um só manifesto cuja substância será retomada, quatro anos mais tarde, no Manifesto do Partido Comunista (e, com vinte anos de distância, em O capital)" (Rubel, 1994, p. xix).

Segundo Rubel, "num de seus cadernos de estudos de sua estada berlinense, conta-se nada menos de 160 trechos do Tratado Teológico-Político de Espinosa. As passagens referem-se aos milagres, à fé e à filosofia, à razão e à teologia, à liberdade de ensino, aos fundamentos da república, ao profetismo, etc. Tudo isso, sem o menor comentário pessoal - e no entanto, sobre a capa do caderno pode-se ler: 'Espinosa: Tratado Teológico-Político, por Karl Marx, Berlim 1841"' (Rubel, 1974, p. 172). 
Publicado na primavera (parisiense) de 1844 no único número dos Anais franco-alemães, A questão judaica constitui parte desse momento-chave de definição intelectual e política de Marx. O cerne de sua argumentação situa-se na - já abordada - crítica à separação entre sociedade civil e Estado, entre homem e cidadão. Marx parte de uma crítica a Bruno Bauer - em seu livro A questão judaica e no artigo "A aptidão dos judeus e dos cristãos contemporâneos a tornar-se livres", ambos de 1843 -, pois Bauer exige "que o judeu renuncie ao judaísmo e em geral o homem à religião para serem emancipados de forma cidadã" (Marx, 2006a [1844], p. 36). Nesse sentido, Bauer parece defender que o Estado necessita emancipar-se da religião para tornar-se um verdadeiro Estado; um Estado religioso ainda não o é.

Entretanto, Marx deseja ir além, questionando quem deve emancipar-se e de que tipo de emancipação se trata. Bauer atém-se a uma crítica do Estado cristão, poupando assim o Estado tout court e esquecendo as relações - e conflitos - entre emancipação política e emancipação humana. Marx problematiza os termos colocados por Bauer. Enquanto este pergunta aos judeus se eles têm o direito de aspirar à emancipação política, Marx inverte a questão, interrogando se "o ponto de vista da emancipação política permite reclamar do judeu a abolição do judaísmo, de reclamar ao homem em geral a abolição da religião?" (Marx, 2006a [1844], p. 37). Seu questionamento da separação estatal continua quando afirma que a emancipação política tem a seguinte limitação decisiva: "O Estado pode se liberar de uma barreira sem que o homem seja realmente liberado dela, que o Estado pode ser um Estado livre sem que o homem possa ser um homem livre" (Marx, 2006a [1844], p. 39-40), ponto que será retomado mais de trinta anos depois, a respeito do Programa de Gotha.

Marx discute a diferença entre os direitos do homem e do cidadão. Quem é esse homem distinto do cidadão? - pergunta. Trata-se da pessoa enquanto membro da sociedade civil, indicando a separação entre Estado político e sociedade civil e marcando, também, a diferença entre emancipação política e humana. Que significa essa separação? Os direitos distintos, do homem e do cidadão, dizem respeito aos direitos como membro da sociedade civil e sua separação da "coisa pública". Não se configura como um direito ligando “o homem ao homem”, mas um que marca sua separação: o indivíduo restrito a si mesmo, egoísta. Ou seja, "a aplicação prática do direito do homem à liberdade é o direito do homem à propriedade privada", como o direito de 
gozar de sua fortuna, independentemente da sociedade, o direito ao egoísmo, de ignorar outrem. Tal liberdade individual funda a sociedade civil e, dessa forma, "deixa cada homem encontrar nos outros homens não a realização mas ao contrário o limite de sua liberdade" (Marx, 2006a [1844], p. 56). O homem como cidadão é o homem burguês.

A emancipação política é a revolução (contra o feudalismo) da sociedade civil. Nesse sentido, "questionar o jugo político, era ao mesmo tempo quebrar os entraves que deixavam cativo o espírito egoísta da sociedade civil. A emancipação política foi ao mesmo tempo a sociedade civil se emancipando da política, da aparência mesmo de um conteúdo geral” (Marx, 2006a [1844], p. 61). Do idealismo do Estado para o materialismo da sociedade civil. Tal como na Crítica de 1843, trata-se de vencer a abstração para alcançar a emancipação humana:

É somente quando o homem individual real reintegrará nele o cidadão abstrato e se tornará homem individual na vida empírica, no seu trabalho individual, nas suas relações individuais, um ser pertencendo à espécie, que o homem terá reconhecido e organizado suas forças próprias como forças sociais e não separará mais dele a força social sob a forma da força política. É somente assim que a emancipação humana será realizada (Marx, 2006a [1844], p. 63).

Uma revolução outra, para além da francesa; radical. Marx faz uso do debate acerca da "questão judaica" para refletir sobre os limites da emancipação política e prosseguir na sua crítica do Estado político. O erro de Bauer, para Marx, consiste em pensar a questão da emancipação dos judeus numa ótica religiosa e, consequentemente, sua solução de modo teológico. Indo contra as cisões modernas, entre homem e cidadão, espaço público e privado, bem comum e interesses egoístas, Marx defende, contra a alienação em suas múltiplas formas (religiosa, social, política), a emancipação não do Estado da religião, mas do Estado mesmo, pela luta.

Marx segue na linha argumentativa dos Manuscritos de Kreuznach, na qual o desvanecimento do Estado conjuga-se com a verdadeira democracia. No entanto, trata-se de uma perspectiva ainda teórica, sem conexão com sujeitos concretos. Em um período de plena mutação e descobertas, Marx, partindo da defesa, em 1842, da liberdade de imprensa e de um espaço público incorporando os direitos dos costumes, pensa, em 1843, a verda- 
deira democracia e liga-a, em 1844, à revolução. Como vimos no primeiro capítulo, há que enfatizar o papel essencial das lutas nessa trajetória, já que seus questionamentos enriquecem-se e transformam-se com a chegada de Marx a Paris e o contato com o movimento operário local.

De acordo com Rubel (1994, p. xlvix), a Introdução à Crítica da filosofia do direito de Hegel, escrita já em Paris, é a continuação necessária e a conclusão lógica de $A$ questão judaica, ambos publicados no mesmo número dos Anais Franco-Alemães. Marx afirma, nesse contexto, a necessidade de uma revolução radical e o papel-chave do proletariado, relacionando-os com o fim da distinção Estado-sociedade. Marx questiona os anseios alemães por uma revolução "meramente política que deixa de pé os pilares do edifício" e a esta opõe uma "revolução radical, a emancipação humana universal" (Marx, 2005b [1844], p. 154). Aprofunda, assim, suas interrogações, pensando em que parte da sociedade poderia existir concretamente outra forma de relação entre universal e particular, ou seja, quem poderia cumprir uma função revolucionária levando ao universal.

Que "representante geral" ligaria particular e universal? Quem a partir de sua condição particular poderia atingir tal universalidade? Marx inicia com uma definição negativa, dada a necessidade de haver coincidência entre uma classe particular e a revolução de um povo, uma "outra classe tem que concentrar em si todos os males da sociedade, um estamento particular tem de ser o estamento do repúdio geral". A luta decisiva toma a forma de um estamento da libertação contra o da opressão. Onde existe, na Alemanha, a possibilidade positiva de emancipação? Para Marx, "na formação de uma classe que tenha cadeias radicais, de um estamento que seja a dissolução de todos os estamentos, de uma esfera que possua caráter universal porque seus sofrimentos são universais" (Marx, 2005b [1844], p. 154-155). Esta define-se como

uma seção da sociedade que viva o mal em geral e não particular, não exigindo, assim, uma reparação particular. Que alcance o humano. Por fim, uma parte impossibilitada de emancipar-se sem as demais esferas da sociedade, uma parte que "só pode redimir-se a si mesma por uma redenção total do homem. A dissolução da sociedade, como classe particular, é o proletariado (Marx, 2005b [1844], p. 156).

Com e contra Hegel, que havia trabalhado em 1821 a ideia do "Stand universal" na sua Filosofia do direito, Marx propõe o proletariado como uma 
“'classe universal', uma massa situada virtualmente além da condição de classe, cuja particularidade já seria negada em suas condições de existência” (Balibar, 1995, p. 65). Um deslocamento decisivo ocorre do povo do Manifesto de Kreuznach ao proletariado de sua Introdução um ano depois. O mistério de sua existência e a "dissolução da ordem social existente" ligam-se à abolição da propriedade privada, concretizando o que o proletariado antecipa na sua negatividade, já que não possui propriedade. Política e economia ligam-se; "ao declarar o povo como sua propriedade privada, o rei afirma simplesmente que quem detém a propriedade privada é rei” (Marx, 2005b [1844], p. 156).

Nesse mesmo ano, além do contato com as lutas operárias parisienses, Marx é interpelado pelo levante dos tecelões da Silésia. Esse é o contexto de suas glosas críticas ao artigo “O rei da Prússia e a reforma social'. De um prussiano”. De um lado, sua caracterização e pensamento sobre o Estado prosseguem. De outro lado, novos elos entre pensamento e as lutas se formam e se desenvolvem, o que terá um desdobramento a respeito do Estado. Nesses comentários, Marx entende que o Estado busca situar-se acima da ordem, no âmbito do inquestionável, do natural. O autor reitera a separação moderna entre Estado e sociedade, sendo este caracterizado como uma máquina de abstração. Retomando a distinção já tratada em A questão judaica, Marx coloca que "o Estado não pode suprimir a contradição entre a finalidade e a boa vontade da administração, por um lado, e seus meios e sua capacidade, por outro, sem suprimir a si próprio", já que "ele está baseado na contradição entre vida pública e vida privada, na contradição entre os interesses gerais e os interesses particulares" (Marx, 2010a [1844], p. 39).

Tal perspectiva de continuidade com os três textos anteriores transforma-se com um acontecimento histórico preciso, a insurreição dos tecelões em junho de 1844 na Silésia. Para Marx, esta desempenhou um papel de "catalisador" das suas reflexões e vivências nos meses anteriores em Paris; uma "reviravolta teórico-prática", a partir de uma indicação concreta da "tendência potencialmente revolucionária do proletariado" (Löwy, 2002, p. 134). Esse levante vai na linha do questionamento dos entendimentos hegelianos da política, mas igualmente da "concepção feuerbachiana da relação entre a filosofia e o mundo, a teoria e a prática. Ao descobrir no proletariado o elemento ativo da emancipação, Marx, sem se referir até então a Feuerbach, rompe com o esquema que ainda era o seu no começo de 1844" (Löwy, 2010, p. 13-14). Os filósofos não mais são os guias da ação, nem o proletariado 
o elemento passivo da revolução. Nesse âmbito, pela primeira vez "Marx associa diretamente o tema do desvanecimento do Estado ao conceito de revolução" (Pogrebinschi, 2009, p. 50).

Os Manuscritos de 1844 indicam uma continuidade do "acerto de contas" com Hegel e concluem o que se chama aqui - com Rubel - de manifesto político (em cinco tempos). Marx efetua, desse modo, um tipo de balanço da crítica ao seu mestre. Afirma, nesse contexto, que, "em Hegel, a negação da negação não é a confirmação da verdadeira essência”, mas sim “a confirmação da essência aparente ou da essência estranhada de si em sua negação ou a negação dessa essência aparente enquanto uma essência objetiva, habitando fora do homem e independentemente dele, e sua transformação no sujeito" (Marx, 2004 [1844], p. 130).

Isso toma forma, na questão política e estatal, de um status quo; "na filosofia do direito de Hegel, o direito privado supra-sumido = moral, a moral supra-sumida = família , a família supra-sumida = sociedade civil , a sociedade civil supra-sumida = Estado, o Estado supra-sumido = história mundial" (Marx, 2004 [1844], p. 130). Os dois enigmas colocados por Marx se cruzam; por um lado, a democracia como enigma resolvido de toda constituição formulada em 1843, por outro, o comunismo sendo "o enigma resolvido da história” (Marx, 2004 [1844], p. 105), pensado um ano depois. Democracia e comunismo entrelaçam-se; "a verdadeira democracia é o momento do vir-a-ser do comunismo. O comunismo é, assim, o movimento que se completa no momento da verdadeira democracia" (Pogrebinschi, 2009, p. 274). Ou, nas palavras de Engels, "a democracia de nosso tempo é o comunismo" (Claudin, 1985, p. 39).

Em perspectiva semelhante, Shlomo Avineri defende que "o que Marx qualifica de 'democracia' não é fundamentalmente diferente do que ele chamará mais tarde de 'comunismo', e de qualquer forma essa 'democracia' baseia-se na 'essência comunista do homem"' (Avineri, 1968, p. 34). Tal vínculo entre a crítica da economia e a da política é reiterado na primeira obra escrita pelos dois parceiros, Marx e Engels, A sagrada família. Nesta, os autores continuam a crítica às abstrações e apontam os elos entre Estado e propriedade privada, ao afirmarem que "o Estado, a propriedade privada e assim por diante transformam os homens em abstrações, ou como os produtos são homens abstratos, em vez de serem a realidade do homem individual e concreto" (Marx e Engels, 2003 [1844], p. 216). 
Os anos de 1842-1844 indicam, em resumo, uma transição, na qual se formam conceitos determinantes do projeto - intelectual e político - marxiano, tais como sua perspectiva de superar a propriedade privada e o Estado, o proletariado como sujeito e os vínculos entre teoria e lutas. Partindo, em 1842, da reivindicação do direito dos costumes para os pobres que nada possuem, nos dois anos seguintes vemos a Introdução transformar o povo da Crítica em proletariado e os Manuscritos de 1844 definirem o comunismo como a verdadeira democracia. Ao fim desse período, Marx é obrigado a deixar Paris e iniciar seu segundo período de exílio, em Bruxelas, de fevereiro de 1845 a março de 1848. Uma nova etapa se abre. Com Engels, Marx vai consolidar sua compreensão do comunismo, prosseguir na crítica da economia política (já iniciada nos Manuscritos parisienses) e, pela primeira vez, participar de uma organização política, isso tudo numa nova (e revolucionária) conjuntura.

\section{Militância comunista e período revolucionário de 1848}

Marx prossegue seus estudos sobre a política e o Estado. Num primeiro momento, trata-se de consolidar certas conclusões teóricas, o que é efetuado, junto com Engels, em $A$ ideologia alemã. A isso agregam-se dois elementos novos: um engajamento político - simbolizado pela redação, com Engels, do Manifesto comunista - e uma conjuntura europeia revolucionária que alimenta suas análises.

Marx traça planos, em 1845, de trabalhar seu manifesto político de 1843-1844 na forma de um livro, sistematizando suas perspectivas sobre o Estado e a política. Essa obra foi objeto de um contrato assinado por Marx com o editor Leske, de Darmstadt, Alemanha (Rubel, 2002, p. 557n). O título desse projeto de obra, Crítica da política e da economia política, indica nitidamente a imbricação, já apontada na seção anterior, das preocupações políticas e econômicas, dos dois enigmas. Num dos cadernos de trabalho de Marx, encontram-se 11 notas, balanço dos seus estudos desde o fim da Gazeta Renana no início de 1843 e que seriam a base da primeira parte desse livro - a crítica da política. Eis os onze pontos:

i) A história da formação do Estado moderno ou a Revolução Francesa (...)

ii) A proclamação dos direitos do homem e a constituição do Estado. A liberdade individual e o poder público. 
Liberdade, igualdade e unidade. A soberania popular.

iii) O Estado e a sociedade civil.

iv) $\mathrm{O}$ Estado representativo e as cartas constitucionais.

O Estado constitucional representativo, o Estado democrático representativo.

v) A divisão dos poderes. Poder legislativo e poder executivo.

vi) O poder legislativo e os corpos legislativos. Clubes políticos.

vii) O poder executivo. Centralização e hierarquia. Centralização e civilização política. Federalismo e industrialismo. Administração do Estado e administração comunal.

viii) ' $\mathrm{O}$ poder judiciário e o direito.

"A nacionalidade e o povo.

ix) 'Os partidos políticos.

"O sufrágio, a luta pela superação do Estado e da sociedade civil (Marx, 2007 [1845], p. 543).

Não por acaso, o derradeiro ponto trata da abolição do Estado, ponto-chave do pensamento político marxiano. Se tal obra não se concretizou, pode-se dizer que $A$ ideologia alemã (Marx e Engels, 2007 [1845-1846]) segue esse curso de, nas palavras de Marx, "desenvolver nossa concepção comum, opondo-a às visões ideológicas da filosofia alemã; de fato, acertar nossas contas com nossa consciência filosófica anterior”. Escrita no início do período dos dois amigos em Bruxelas, essa obra tampouco foi publicada. Entretanto, de acordo com Marx, "tínhamos atingido o objetivo principal: $a$ boa inteligência de nós-mesmos. De boa graça, abandonamos o manuscrito às críticas roedora dos ratos" (Marx, 2009b [1859], p. 490).

São poucos os trechos que apreendem diretamente o Estado, mas indicam uma síntese provisória de seus conhecimentos e reflexões sobre a máquina estatal e a ação proletária frente a esta. Marx e Engels retomam e consolidam pontos já abordados antes, presentes igualmente nas notas preparatórias para o livro citado acima, como o caráter ilusório da comunidade política, mas, também, apontam elementos novos. Devido à contradição do interesse particular com o interesse coletivo, tal organização política "assume, como Estado, uma forma autônoma, separada dos interesses singulares e gerais" (Marx e Engels, 2007 [1845-1846], p. 37). E, em certos contextos - "naqueles países onde os estamentos não se desenvolveram completamente até se tornarem classes" (Marx e Engels, 2007 [1845-1846], p. 75) -, tal autonomia 
se reforça, os autores pensando essencialmente na Alemanha. Alguns anos mais tarde, Marx retomará esse conceito no caso francês.

Ligando-nos à discussão do primeiro capítulo, nessa obra, Marx e Engels colocam que "por meio da emancipação da propriedade privada em relação à comunidade, o Estado se tornou uma existência particular ao lado e fora da sociedade civil” (Marx e Engels, 2007 [1845-1846], p. 75). A dissolução da comunidade coincide com a formação do Estado e o surgimento da propriedade privada. O Estado é analisado, ademais, como esfera em que a classe dominante produz politicamente seus interesses comuns e "que sintetiza a sociedade civil inteira de uma época". Desse modo, "todas as instituições coletivas são mediadas pelo Estado, adquirem por meio dele uma forma política. Daí a ilusão, como se a lei se baseasse na vontade e, mais ainda, na vontade separada de sua base real, na vontade livre" (Marx e Engels, 2007 [1845-1846], p. 76).

No contexto das lutas da classe trabalhadora, os autores pensam, pela primeira vez, num poder proletário; "toda classe que almeje à dominação, como é o caso do proletariado, exija a superação de toda a antiga forma de sociedade e a superação da dominação em geral, deve primeiramente conquistar o poder político, para apresentar seu interesse como o interesse geral". Tal questão será retomada no Manifesto e liga-se à polêmica posterior com Bakunin (e Lassalle), estudada adiante. Uma primeira concepção de transição surge nessa obra. Marx e Engels criticam os que se atêm às "lutas no interior do Estado" (Marx e Engels, 2007 [1845-1846], p. 37) e reafirmam a luta proletária contra o Estado; estes "têm de suprassumir sua própria condição de existência anterior, isto é, o trabalho" e, por isso, "em oposição ao Estado, a forma pela qual os indivíduos se deram, até então, uma expressão coletiva, e têm de derrubar o Estado para impor a sua personalidade" (Marx e Engels, 2007 [1845-1846], p. 66).

Além disso, Marx e Engels pensam numa outra relação entre indivíduo e sociedade. Se, no âmbito burguês, os indivíduos no seio de uma classe tinham seus interesses condicionados por sua existência como membros desta, como "indivíduos médios", isso pode tomar um outro sentido (proletário), pois "com a coletividade dos proletários revolucionários, que tomam sob seu controle suas condições de existência e as de todos os membros da sociedade, dá-se exatamente o inverso: nela os indivíduos participam como indivíduos". Surge um ponto fundamental, pois os autores pensam a ação proletária em 
sua positividade, esta encarnando uma união de novo tipo, uma "associação de indivíduos" que permite o "livre desenvolvimento" (Marx e Engels, 2007 [1845-1846], p. 66-67). E isso é contraposto à união anterior (burguesa), situada num mundo reduzido, e marca uma transição. Satisfeitos com suas conclusões teóricas, os autores passam a pensar em ganhar o proletariado e "começam a estabelecer relações regulares de informação e discussão com elementos destacados do movimento socialista e comunista de diversos países europeus, principalmente Alemanha, França e Inglaterra" (Claudin, 1985, p. 51). É criado o Comitê Comunista de Correspondência em Bruxelas.

O comunismo é entendido não mais como fantasia ou ideal, mas como uma possibilidade concreta, esboçada nos movimentos alemão e francês e nos cartistas ingleses. Tal perspectiva faz-se presente na sequência de textos a partir de A ideologia alemã até o Manifesto. A elaboração acerca de uma associação como nova forma de organização prossegue em Miséria da filosofia. Segundo Marx, a classe trabalhadora substituirá a antiga sociedade civil por "uma associação que excluirá as classes e seu antagonismo, e não haverá mais poder político propriamente dito, já que o poder político é precisamente o resumo oficial do antagonismo na sociedade civil" (Marx, 2002b [1847], p. 232). Ou seja, o protagonismo do proletariado liga-se à abolição do Estado, sua ação é contra o Estado.

Marx, nesse período, reforça, igualmente, o estudo das bases materiais do Estado, investigando os elos entre economia e dominação política. Em seu embate contra Proudhon, o autor aponta sua incapacidade de compreender os desenvolvimentos econômicos, encontrados no âmbito da sociedade civil. Pergunta Marx, em carta ao russo Pavel Annenkov, o que é a sociedade, definindo-a como a ação recíproca dos homens. Mas, prossegue Marx, são eles livres para escolher a formação social desejada? Não, e essas formas devem ser pensadas no contexto do "estado de desenvolvimento das faculdades produtivas dos homens" - ou seja do grau de desenvolvimento da produção, comércio e consumo - que indicam a "forma de constituição social, tal organização da família, das ordens ou das classes, em uma palavra tal sociedade civil. Coloque tal sociedade civil, e vocês terão tal Estado político, que é somente a expressão oficial da sociedade civil” (Marx, 2002a [1846], p. 70).

Já no Manifesto do Partido Comunista, Marx e Engels colocam que, "com o estabelecimento da grande indústria e do mercado mundial a burguesia conquistou, finalmente, o domínio político exclusivo no Estado represen- 
tativo moderno". Dessa forma, "o poder do Estado moderno não passa de um comitê que administra os negócios comuns da classe burguesa como um todo" (Marx e Engels, 2001 [1848], p. 10). E, nas dez medidas propostas, o Estado aparece com destaque, como instrumento de centralização do crédito, o que abre alguma ambiguidade, que será explorada por Bakunin e corrigida em prefácio posterior.

Porém, o ímpeto contra o Estado se faz presente e liga-se, nesse Manifesto e no período posterior, à abolição das classes. Com a supressão violenta das velhas relações de produção e, assim, dos antagonismos de classe, a produção passa a ser "concentrada nas mãos dos indivíduos associados". Nesse sentido, dizem Marx e Engels, “o poder público irá perder seu caráter político” (Marx e Engels, 2001 [1848], p. 28). O que significa essa perda do caráter político? Que já não se trata do sentido habitual de Estado. Os autores pensam no contexto da futura centralização dos meios de produção e, desse modo, o “Estado’ aqui já não é mais propriamente Estado, mas uma nova forma política em processo de constituição e que temporariamente tem o proletariado em seu leme" (Pogrebinschi, 2009, p. 95). Uma forma mais explícita encontra-se em resenha de 1850 do livro Le socialisme et l'impôt, de Emile de Girardin. Nesta, Marx coloca que "a abolição do Estado tem apenas um sentido para os comunistas, como a consequência necessária da abolição de classes, em virtude do que por si mesma a necessidade da força organizada de uma classe para a supressão da outra deixa de existir" (Pogrebinschi, 2009, p. 32).

A abolição do Estado é consequência, mas, ao mesmo tempo, causa; “o movimento parece definitivamente afirmar-se em mão dupla, além de marcar-se pela concomitância” (Pogrebinschi, 2009, p. 56). Isso se liga a uma fórmula-chave do Manifesto, na qual "no lugar da velha sociedade burguesa, com suas classes e seus antagonismos de classe, surge uma associação em que o livre desenvolvimento de cada um é pressuposto para o livre desenvolvimento de todos" (Marx e Engels, 2001 [1848], p. 29).

Esse Manifesto marca a adesão da Liga dos Justos, transformada em Liga dos Comunistas, às ideias de Marx e Engels. Nesse plano, "o problema do Estado não é abordado por Marx e Engels, nesse período pré-revolucionário, de modo específico; não dizem o que vai se fazer com a organização estatal anterior estatal nem como vai ser a nova" (Claudin, 1985, p. 41). As insurreições de 1848, que ocorrem em toda a Europa continental (Paris, Prússia, 
norte e sul da Itália, Hungria...) pouco após a publicação do Manifesto, vão alimentar decisivamente as reflexões de Marx, nos quatro anos seguintes.

Nesse sentido, o continuum marxiano contra o Estado mostra-se nesses escritos e liga-se à revolução. Em Luta de classes na França, Marx pensa a "declaração da revolução em permanência" como transição necessária para "a abolição das diferenças de classes", concretizando o "revolucionamento de todas as ideias que nascem dessas relações sociais" (Marx, 2002c [1850], p. 122). Em sentido semelhante, na Mensagem do Comitê Central à Liga dos Comunistas, os autores defendem uma ação autônoma dos trabalhadores frente aos demais partidos, sugerindo que "seu grito de guerra deve ser: a revolução em permanência” (Marx e Engels, 2010 [1850], p. 75).

Marx e Engels afirmam, ainda, o objetivo proletário de constituição de seu próprio poder na forma de conselhos e órgãos “endógenos" (operários) frente à democracia dos burgueses. Devem, assim, produzir "seus próprios governos operários revolucionários, seja na forma de municipalidades ou de conselhos municipais, seja por clubes ou comitês operários" (Löwy, 2002, p. 227), sendo uma forma de controle, pressão e ameaça contra os governos burgueses. Tal associação não se liga à centralização burguesa e estatal. Se, em 1850, Marx e Engels dirão que, "como foi o caso na França em 1793, hoje na Alemanha a execução da mais rígida centralização é a tarefa do partido realmente revolucionário" (Marx e Engels, 2010 [1850], p. 73), Engels corrigirá isso em nota à edição de 1885, defendendo que

é preciso lembrar hoje que essa passagem se baseia num mal-entendido. Naquela época - graças aos falsificadores bonapartistas e liberais da história -, dava-se por assentado que a máquina administrativa centralizada dos franceses havia sido introduzida pela grande Revolução e utilizada principalmente pela Convenção como arma indispensável e decisiva para derrotar a reação monarquista e federalista e o inimigo externo. Agora, porém, é fato conhecido que, durante todo o período da revolução até o 18 de brumário, toda a administração dos départements, dos arrondissements e das comunas era formada por autoridades eleitas pelos próprios administrados, as quais se moviam com inteira liberdade no âmbito das leis gerais do Estado; sabe-se agora que esse autogoverno provincial e local, semelhante ao norte-americano, foi a alavanca mais poderosa da Revolução, e tanto o foi que Napoleão, imediatamente após o seu golpe de Estado em 18 de brumário, apressou-se a substituí-lo pelo sistema dos prefeitos vigentes ainda hoje, o qual desde o princípio foi, portanto, puro instrumento da reação. Porém, assim como o autogoverno local e provincial não 
está em contradição com a centralização nacional de cunho político, tampouco está necessariamente atrelado àquele egoísmo cantonal ou comunal estreito, com cuja face asquerosa nos deparamos na Suíça e que, em 1849, todos os republicanos federalistas do sul da Alemanha queriam tornar regra para toda a Alemanha (Engels, $1996[1885$, p. 73).

Ademais, a reflexão acerca do estatal se reforça em 18 de Brumário de Luís Bonaparte. Sua análise do bonapartismo retoma e reforça a questão da autonomia do Estado frente à sociedade, já esboçada em $A$ ideologia alemã. Como o golpe de Luís Bonaparte, Marx lamenta que, "em vez da sociedade ela mesma ter se dado um novo conteúdo, o Estado parece ter voltado à sua forma primitiva, à simples dominação insolente do sabre e do hissope" (Marx, 1997 [1852], p. 18). O bonapartismo lê-se, assim, como a supremacia do poder executivo, o antagonismo acentuado ao máximo entre Estado e sociedade civil. Tal poder estatal hipertrofiado deriva de características singulares da França (raízes na monarquia absoluta e sua luta contra todos os poderes locais, territoriais, provinciais), com um "exército de funcionários" de meio milhão de pessoas que lhe permite garantir a dependência contínua de distintos setores e interesses.

O Estado é visto como um corpo parasita e "controla, regulamenta, vigia e tutela a sociedade civil", esta estando, por sua vez, em "estado de dependência absoluta" e indicando uma "disformidade incoerente do corpo social" frente a essa "máquina governamental vasta e complicada" (Marx, 1997 [1852], p. 79-80). Na monarquia absoluta, na Revolução Francesa e sob Napoleão, "a burocracia só era o meio de preparar a dominação de classe da burguesia”. Com Luís Felipe e sua República parlamentar, "ela era o instrumento da classe dominante" e ganha tal autonomia somente "sob o segundo Bonaparte, no qual o Estado parece ter virado completamente independente" (Marx, 1997 [1852], p. 169).

Tal autonomia não é incompatível com sua representação de interesses particulares, já que "o poder do Estado não plana nos ares. Bonaparte representa uma classe bem determinada, e mesmo a classe mais numerosa da sociedade francesa, a saber os camponeses parcelários". Marx percebe uma continuidade nesses processos franceses, a saber, que "todas as revoluções políticas só aperfeiçoaram essa máquina, em vez de a quebrar” (Marx, 1997 [1852], p. 169), sendo que os partidos lutaram todos pela conquista desse 
imenso edifício como principal troféu. Reafirmando sua perspectiva contra o Estado, liga essa análise a um "apelo", para que a próxima revolução proletária não o faça, defendendo que a "destruição do aparelho de Estado não colocará em perigo a centralização", a burocracia sendo uma "forma inferior e brutal de centralização, que está ainda afetada pelo seu contrário, o feudalismo" (Marx, 1997 [1852], p. 181).

Entre 1848 e 1852, Marx percebe o "papel primordial - sem precedentes históricos comparáveis - desempenhado pela máquina do Estado (exército, burocracia, magistratura...) no sufocamento da explosão revolucionária" (Claudin, 1985, p. 335). E o autor prega, como vimos, uma demolição do aparelho burocrático-militar "pletórico, parasita e hipercentralizado" e não sua tomada "como um troféu". Segundo Rubel, nesse 18 de Brumário "encontram-se reunidos os elementos fundamentais, e definitivos sem dúvida, da sociologia política de Marx. De fato, nós os reencontramos quase idênticos no Manifesto sobre a Comuna, escrito quase vinte anos mais tarde" (Rubel, 2002, p. 473).

Ainda nesse ano de 1852, a Liga dissolve-se. Marx concentra-se, a partir desse momento, no estudo e na crítica da economia política, "recusando sistematicamente (assim como Engels) qualquer participação em organizações” (Claudin, 1985, p. 326), até 1864, quando tomará parte da fundação da Associação Internacional dos Trabalhadores.

\section{A crítica da economia política}

Marx retoma o plano de escrever um livro desenvolvendo sua crítica da política. Em fevereiro de 1858, o autor escreve para Lassalle pedindo ajuda para encontrar um editor em Berlim. A obra seria intitulada Contribuição à crítica da economia política, sendo dividida em seis livros, dos quais o quarto trataria do Estado (Marx, 1858). Tal ideia também é citada numa carta de 28 de dezembro de 1862 a Kugelmann. Discorrendo sobre seu O capital em elaboração, Marx afirma que este aborda o que os ingleses denominam the principles of political economy e que a continuação disso poderia ser efetuada por outros autores, "exceto talvez a relação entre as diversas formas de Estado e as diferentes estruturas econômicas da sociedade" (Marx, 1862, p. 29).

Como vimos, desde os anos 1840, Marx preocupa-se com os elos entre economia e política. Em 1844, Engels - num livro que Marx qualificou de "genial esboço de uma crítica das categorias econômicas" (Marx, 2009b 
[1859], p. 490) - pensa nas relações entre essas duas esferas, colocando que "a política não pensava em questionar os fundamentos do Estado em si. Da mesma forma, a economia não se preocupava em criticar a legitimidade da propriedade privada" (Marx, 2004 [1844], p. 10). Quais os desenvolvimentos nessa fase de crítica da economia política? Marx concentra-se nas formas materiais que sustentam as formas de Estado. $\mathrm{Na}$ "Introdução geral" à Crítica da economia política, Marx toca nisso ao colocar que "Hegel, por exemplo, começa corretamente a "filosofia do direito" pela propriedade, que é a relação jurídica mais simples do sujeito” (Marx, 2009a [1857], p. 472). As formas de Estado, assim como as relações jurídicas, não podem ser explicadas por si mesmas, mas sim nas condições materiais da vida "que Hegel, a exemplo dos ingleses e dos franceses do século 18, compreende em seu conjunto sob o nome de 'sociedade civil'; e é na economia política que convém investigar a anatomia da sociedade civil" (Marx, 2009a [1857], p. 488).

Numa época revolucionária, os fundamentos econômicos transformam-se rapidamente, com repercussões em todos planos; do ponto de vista material (produção econômica) e também nas "formas ideológicas, nas quais os homens tomam consciência desse conflito e o levam até o fim" (Marx, 2009a [1857], p. 489). Na linha dos Grundrisse, no livro 3 de O capital, Marx coloca que

é neste fundamento que se constitui a comunidade econômica tal como nasce nas relações de produção e é sobre este que repousa igualmente a estrutura política específica da comunidade. É sempre nas relações imediatas entre os mestres das condições de produção e os produtores diretos que deve-se buscar o segredo íntimo, o fundamento escondido de toda a estrutura social, assim como a forma política das relações de soberania e dependência, ou seja, a forma de Estado numa época histórica dada. Em seus diversos aspectos, estas relações correspondem naturalmente a um estágio determinado da evolução dos métodos de trabalho e da produtividade social (Marx, 2010b [1894], p. 1962-1963).

Lawrence Krader parece ter razão ao afirmar que "os problemas tratados em 1841-1846 permaneceram substancialmente os mesmos durante o período 1857-1867, quando os Grundrisse e os volumes de O capital foram redigidos" (Krader, 1974, p. 5). Marx levanta, no entanto, um novo e determinante ponto em $O$ capital, a saber a "gênese extra-econômica da propriedade" 
(Mezzadra, 2008, p. 136). É nesse sentido que François Châtelet vê nessa obra de Marx uma "onipresença do político" (Châtelet, 1996 [1975], p. 38), seu assunto sendo "a crítica ao hegelianismo político", devido à sua cegueira quanto ao Estado como "produto das sociedades e de sua organização econômica; que ele encarna, segundo suas particularidades históricas, sob as aparências da legalidade" (Châtelet, 1996 [1975], p. 22-23, grifos no original).

Marx retoma o questionamento da separação entre o econômico e o político e sua crítica da economia política configura-se num "assunto eminentemente político, isto é, tratando do poder, da dominação" (Löwy, 2009, p. 65). Isso se explicita no capítulo sobre a acumulação originária e seu estudo das condições necessárias para o desenvolvimento capitalista, isto é, a expropriação dos produtores e a consequente concentração de riqueza - a acumulação inicial e suas duas facetas: no caso emblemático da Inglaterra e nas políticas coloniais. Nesse sentido, "o século 18 introduz um progresso no sentido que é a lei mesma que torna-se então instrumento da pilhagem das terras do povo", inclusive em sua forma parlamentar - com as leis de cercamento das terras comunais. Estas permitiam "aos proprietários fundiários de fazer a si mesmos presente das terras do povo e de fazer destas sua propriedade privada, ou seja são decretos de expropriação do povo" (Marx, 2006b [1867], p. 815).

O Estado exerce um papel-chave na transição capitalista, na "constituição política e jurídica do 'mercado do trabalho"' (Mezzadra, 2008, p. 139), o que se contrapõe à perspectiva das relações ditas livres; não há nada natural nessa constituição. Marx descreve sua construção sanguinária, com "o povo do campo, brutalmente expropriado e expulso de sua terra, reduzido à vagabundagem, sendo submetido a leis de um terrorismo grotesco, à disciplina necessária ao salariado por meio de chicotadas, marcas ao ferro quente e torturas". Nesse sentido, "a burguesia ascendente necessita e usa a violência do poder de Estado para 'regular' o salário" (Marx, 2006b [1867], p. 828829). Não se trata, entretanto, de uma visão instrumental, pois as leis são apreendidas como resultado das lutas, o Estado contribuindo para a balança pender do lado dos capitalistas/proprietários. A violência do Estado é decisiva para regular as jornadas de trabalho, o ritmo, os salários e as pausas permitidas. Tais leis e acordos desenvolveram-se "progressivamente, em função das condições reais como leis naturais do modo de produção moderno. Sua formulação, seu reconhecimento oficial e proclamação pelo Estado foram o 
resultado de lutas de classes de longo fôlego" (Marx, 2006b [1867], p. 316). Em suma, Marx defende que, entre dois direitos, a força define quem ganha.

A jornada de trabalho indica o "nível empírico [em] que se exerce o poder político do sistema capitalista” (Châtelet, 1996 [1975], p. 63). É interessante notar que, no momento final da redação de $O$ capital, a Associação Internacional dos Trabalhadores (AIT), em seu Congresso de Genebra, defende com um dos seus principais pontos a luta pela limitação legal da jornada de trabalho a oito horas diárias. Segundo a AIT, trata-se de uma reivindicação chave, sendo uma "condição preliminar, sem a qual todas as outras tentativas de melhoria e emancipação devem se mostrar precoces" (Marx, 1974b [1866], p. 87). Para Marx, pensando na influência "diabólica" da Inglaterra sobre o mercado mundial, não há nem leis naturais nem livre mercado. A violência inicial estatal-capitalista liga-se à questão colonial, como vimos no primeiro capítulo. Dessa forma, "estes métodos baseiam-se em parte na violência mais brutal; é esse o caso, por exemplo, do sistema colonial. Mas todas utilizam o poder do Estado, a violência concentrada e organizada da sociedade" (Marx, 2006b [1867], p. 846).

Tal sistema capitalista não se viabiliza sem uma instância política; não é somente um novo modo de produção, mas "resulta de uma operação de poder" e "mesmo sob seus aspectos mais abstratos, mais técnicos, O capital é um livro político de ponta a ponta” (Châtelet, 1996 [1975], p. 79-83). O capitalismo configura-se, assim, como um "sistema econômico-político". Em suma, não há capitalismo sem Estado e percebe-se, assim, um substantivo elo entre $O$ capital e os escritos anteriores estudados. Tanto $O$ capital tem uma problematização do Estado, quanto Marx, em sua crítica inicial a Hegel, já recusa a solução idealista e a propriedade privada. Pode-se falar de duas facetas de um mesmo movimento. Para o antropólogo e filósofo Lucien Sebag, O capital "fornece a verdadeira resposta à Filosofia do Direito ao analisar os mecanismos reais do desenvolvimento da sociedade capitalista" (Sebag, 1964, p. 45), completando sua crítica a Hegel por conta de sua defesa do Estado como única forma capaz de superar as contradições entre as demais esferas da vida social.

Por um lado, “o Estado é um fabricante de abstrações, em razão da ficção unitária (ou do consenso) que ele deve impor à sociedade. A universalização da particularidade é a contrapartida da constituição do Estado" (Balibar, 1995, p. 62), imprimindo uma faceta política à dominação. Por outro lado, 
conjugam-se um "fetichismo econômico das coisas" e um "fetichismo jurídico das pessoas". Ambos unem-se, "porque o contrato é a outra face da troca, e porque cada um é pressuposto pelo outro". Dessa forma, “o mundo vivido e percebido a partir da expressão do valor é na verdade (e Marx indicou isso; era até a razão de sua releitura crítica da Filosofia do direito de Hegel, onipresente no Capital) um mundo econômico-jurídico" (Balibar, 1995, p. 88).

Tais desenvolvimentos marxianos articulam as duas críticas, da economia e da política. Isso está presente, nesse mesmo período, no manifesto de fundação da Associação Internacional dos Trabalhadores e nas suas Provisional rules. Marx coloca que "a emancipação da classe trabalhadora deve ser conquistada pelos próprios trabalhadores” (Marx, 1974a [1866], p. 82), o que pressupõe formas próprias para abolir o domínio de classe. Autoemancipação e auto-organização unem-se e no Congresso de Lausanne da AIT isso é explicitado: "a emancipação social dos trabalhadores é inseparável de sua emancipação política", sendo que "seu movimento econômico e sua ação política são indissoluvelmente unidos” (Marx, 1974c [1867], p. 270).

Democracia e comunismo ligam-se novamente, num tipo de "democracia dos produtores", tendo em vista a problematização da "relação específica entre a representação e o capitalismo. Ou, melhor, a relação entre o autogoverno e o comunismo". A "cooperação é a 'forma econômica' da verdadeira democracia” (Pogrebinschi, 2009, p. 262-263). A cooperação constitui-se numa forma alternativa, criativa e antagonista. Desse modo, chega-se à "definição de um conceito de produção que não é só econômico, mas social e político ao mesmo tempo" (Negri, 2002, p. 409), indicando a indissolubilidade da democracia política e econômica.

Se na década de 1840 e no início da seguinte a abolição do Estado foi trabalhada de modo mais direto, no período subsequente a crítica da economia política predomina e a abolição liga-se "ao fim da propriedade privada e/ou divisão do trabalho" (Pogrebinschi, 2009, p. 53), embora não seja possível separá-las. Na década de 1870, Marx a aborda de forma mais explícita novamente, devido a acontecimentos e debates políticos.

\section{A Comuna de Paris como paradigma}

A Comuna de Paris causa um forte impacto em Marx. Atribuindo uma força considerável a essa breve experiência revolucionária, em 12 de abril de 1871, o autor escreve a Ludwig Kugelmann que "a história não conhece 
outro exemplo de tamanha grandeza!" (Marx, 1971a [1871], p. 188). Cinco dias mais tarde, afirma que "a luta de Paris fez entrar numa nova fase a luta da classe operária contra a classe capitalista e seu Estado. Independente do desenlace imediato, ela permitiu a conquista de uma nova base de partida de uma importância histórica universal" (Marx, 1971b [1871], p. 191).

Em A guerra civil na França, resolução do Conselho Geral da Associação Internacional dos Trabalhadores, Marx afirma que "os trabalhadores de Paris, com sua Comuna, serão celebrados para sempre como gloriosos arautos da nova sociedade. Seus mártires estão enraizados no grande coração da classe trabalhadora" (Marx, 1971d [1871], p. 97). Engels, quinze anos depois, declara que se trata do "acontecimento mais glorioso e terrível dos anais do proletariado” (Engels, 1886, p. 294). A Comuna possui um caráter fundador como experiência e criação política proletária. Como o pergunta Marx, "o que é a Comuna, essa esfinge tão atormentadora para a mente burguesa?" (Marx, 1971d [1871], p. 69).

Marx mesmo liga tal experiência às suas reflexões anteriores. Como colocado acima, a esfinge política relaciona-se com os enigmas de 1843-1844, e, igualmente, com os acontecimentos (e reflexões sobre) de 1848. Em carta para Kugelmann, ele indica que

se você reler o último capítulo do meu 18 de Brumário verá que ali expresso a seguinte ideia: a próxima tentativa revolucionária na França não deverá ser, como ocorreu até agora, a de fazer mudar de mão o aparelho burocrático-militar, mas sim de esmagá-lo. E é a condição prévia de toda verdadeira revolução popular no continente. É bem isso aliás o que tentam os heróicos camaradas parisienses. Que elasticidade, que iniciativa histórica, que capacidade de sacrifício nos parisienses! (Marx, 1971a [1871], p. 150).

O Estado é analisado como crescentemente opressor, pois “após cada revolução (...), o caráter puramente repressivo do Estado aparece cada vez mais forte" (Marx, 1971d [1871], p. 71). Nesse contexto, Marx expõe um ensinamento chave da Comuna de Paris - "a classe trabalhadora não pode simplesmente tomar a máquina do Estado já pronta e usá-la para seus próprios propósitos" (Marx, 1971d [1871], p. 70) -, retomado em prefácio ao Manifesto no ano seguinte. Trata-se de uma retificação que dissipa uma ambiguidade presente em outros momentos. 
Tal máquina estatal com seus organismos, tais como o exército permanente, a polícia, a burocracia, o clero e a magistratura, embebe-se e organiza-se segundo "o plano de uma sistemática e hierárquica divisão do trabalho, cuja origem situa-se nos dias da monarquia absoluta, servindo à nascente sociedade de classe média como uma arma poderosa nas suas lutas contra o feudalismo" (Marx, 1971d [1871], p. 70). Aqui se percebe uma correção implícita daquele trecho sobre a Revolução Francesa como origem da centralização, o que é feito explicitamente, como vimos na nota de Engels de 1895, da monarquia absoluta, do Estado absoluto. Marx "pode desde esse momento abandonar o projeto de estrita centralização das formas políticas revolucionárias ao nível nacional, vigorosamente defendida ao longo das revoluções de 1848" (Kouvélakis, 2004) para um processo mais complexo de arranjos locais, regionais e nacional, com níveis de autonomia.

Antítese do Império, a Comuna opõe-se à forma monárquica e à dominação de classe. E, sobretudo, constitui-se de modo positivo - de criação de outras formas - graças a medidas concretas. A primeira situa-se na supressão do exército permanente e do caráter político da polícia, substituindo-os pelo povo em armas. Ademais, a Comuna compõe-se de conselheiros municipais (operários ou ligados à classe operária), eleitos pelo sufrágio universal, com mandatos imperativos e permanentemente revogáveis. O mesmo ocorreu com os demais funcionários públicos - como magistrados e juízes -, que passaram, além disso, a receber salários de operários. Desse modo, "as funções públicas cessam de ser a propriedade privada das ferramentas do Governo Central" (Marx, 1971d [1871], p. 73). Na Comuna de Paris atacou-se, igualmente, o poder da Igreja, expropriando-a; os padres "foram enviados de volta ao recesso da vida privada, para alimentar as almas da mesma forma de seus antecessores, os apóstolos" (Marx, 1971d [1871], p. 73). Além disso, esboça-se uma instrução pública e gratuita para todos, sem ingerência estatal ou eclesial.

Uma forma-comuna contra o Estado e passível de expansão para todos os centros industriais franceses e, também, para uma organização nacional, inclusive do campo. Essas comunas administrariam seus assuntos via uma assembleia local de delegados, reunindo-se depois em capitais regionais e enfim numa delegação nacional em Paris - mantendo, assim, a unidade nacional, sempre com mandatos imperativos e revogáveis. As eleições teriam outro papel com a massiva participação popular. Não mais o momento, mas um momento, consoante com a crítica marxiana da representação. Nesse 
sentido, "em vez de decidir a cada três ou seis anos qual membro da classe dominante iria des-representar o povo", a nova organização política "iria servir ao povo, constituído em Comunas, assim como o sufrágio universal serve qualquer empregador na sua busca por trabalhadores e gerentes nos seus negócios" (Marx, 1971d [1871], p. 74). Tal perspectiva explicita o significado das notas de Marx de 1845, citadas acima, nas quais sufrágio universal e abolição do Estado estavam lado a lado.

Esse governo "quebra [breaks] o poder do Estado moderno" (Marx, 1971d [1871], p. 74), não tendo relação imediata com as comunas medievais, mas sendo formas contemporâneas de produção democrática revolucionária. A quebra desse poder liga-se à luta contra a burocracia e à abolição do Estado. Como colocado por Vladimir Ilitch Lênin, "se todos participam realmente da gestão do Estado, o capitalismo não pode mais se manter" e, desse modo, "em regime socialista, todo mundo governará rotativamente e se acostumará rapidamente a que ninguém governe” (Lénine, 1972 [1918], p. 148-174).

Sua característica potencialmente expansiva está baseada no fato de que "todas as formas prévias de governo foram enfaticamente repressivas" (Marx, 1971d [1871], p. 76). Com forte simbologia, a Comuna executou a queima pública de todas as guilhotinas e a demolição da coluna da Place Vendôme, "um monumento da barbárie, símbolo da força bruta e da falsa glória, uma afirmação do militarismo, uma negação do direito internacional” (Marx, 1971c [1871], p. 141). Logo, “o verdadeiro segredo era esse. Era essencialmente o governo da classe operária, o produto da luta dos produtores contra a classe apropriadora". Trata-se, assim, da "forma enfim encontrada na qual será possível a emancipação do trabalho" (Marx, 1971d [1871], p. 76).

Um governo da classe operária. Tal forma política liga concretamente os dois enigmas e as duas críticas, da economia e da política. Marx retoma, dessa forma, a ideia do comunismo como "movimento real que supera o estado de coisas atual” (Marx e Engels, 2007 [1845-1846], p. 38) e a formulação da negação da negação de $O$ capital. A Comuna de Paris visava à expropriação dos expropriadores e a uma transformação dos meios de produção "agora principalmente meios de escravizar e explorar o trabalho, em meros instrumentos do trabalho livre e associado. - Mas isso é comunismo, o 'impossível' comunismo!" (Marx, 1971d [1871], p. 77).

Marx, contra a "antecipação doutrinária e necessariamente fantasmagórica do programa de ação de uma revolução futura”, vê a Comuna de Paris 
como um processo revolucionário. De acordo com essa compreensão, "a classe trabalhadora não esperava milagres da Comuna. Ela não tinha utopias prontas a introduzir par décret du peuple” (Marx, 1971d [1871], p. 77). Seu principal trunfo situa-se na sua existência mesmo, suas tendências e potencialidades revolucionárias de um governo do povo e pelo povo, pois a Comuna "não tem ideais a realizar, mas liberar os elementos da nova sociedade da qual a colapsante sociedade burguesa é prenhe” (Marx, 1971d [1871], p. 77). Forma e conteúdo harmonizam-se, pois "a emancipação econômica e social do trabalho requer formas políticas por si só emancipadoras”. Dessa forma, "a Comuna foi uma forma de emancipação do trabalho precisamente na medida em que ela não foi um Estado, mas especificamente montada para esmagá-lo" (Sayer e Corrigan, 1987).

De acordo com Pogrebinschi, "uma leitura atenta do texto permite perceber que o tempo verbal empregado em boa parte das passagens descritivas da Comuna é o futuro do pretérito" (Pogrebinschi, 2009, p. 149). Tal expansividade liga-se à economia, ao encontro da verdadeira democracia com o governo dos produtores. E não somente um governo dos trabalhadores, mas também de todos, todos os que não vivem do trabalho alheio, sendo "o verdadeiro representante de todos os setores saudáveis da sociedade francesa e desse modo um verdadeiro governo nacional, sendo, ao mesmo tempo, um governo da classe operária” (Marx, 1971d [1871], p. 80). Nessas palavras, Marx indica a resolução do conflito universal/particular apontado em 18431844. A "forma enfim encontrada" seria um tipo concreto que superaria tal dicotomia. Isso se relaciona com seu decisivo internacionalismo. A Comuna é, assim, "a campeã da emancipação do trabalho, enfaticamente internacional". Nesse âmbito, "a Comuna anexou a França à classe trabalhadora de todo o mundo" (Marx, 1971d [1871], p. 80), admitindo muitos estrangeiros em seu seio e tendo o alemão Frankel, da Internacional, como membro da executiva da Comuna (Marx, 1971c [1871], p. 141).

Esse ímpeto antiestatista marxiano continua em seus últimos estudos. Nos debates com Bakunin e Lassalle, e ao analisar a comuna rural russa nos anos 1880, Marx identifica na opressão estatal o principal adversário desta: "O que ameaça a vida da comuna russa não é nem a inevitabilidade histórica nem uma teoria; é a opressão estatal e a exploração pelos capitalistas intrusos os quais o Estado tornou poderoso em detrimento dos camponeses" (Marx, 1983 [1881], p. 104). 
Balibar defende que Marx efetuou duas retificações nas suas duas últimas décadas de vida, presentes nos dois novos prefácios que escreveu com Engels, para o Manifesto, para a edição alemã de 1872 e para a russa de 1882. Uma dizia respeito ao mir - a comuna rural russa - e suas consequências a respeito da compreensão da história e do progresso. Outra "foi determinada conjuntamente pelo ataque de Bakunin contra a 'ditadura marxista' na Internacional” e, também, "pela discordância de Marx em relação ao projeto de programa redigido em 1875 por Liebknecht e Bebel, para o Congresso de Unificação dos socialistas alemães". Ambas desembocam "naquilo que se chamou mais tarde, no marxismo, questão da 'transição"' (Balibar, 1995, p. 124).

Marx enfatiza a necessidade de uma transformação das condições materiais e, nesse sentido, "se o objetivo é a auto-emancipação do trabalho, os meios têm de ser 'prefiguradores', pois estes são os únicos que funcionarão" (Sayer e Corrigan, 1987, p. 80). O pensamento político marxiano lança pistas para o que seria uma democracia revolucionária.

\section{Referências}

ABENSOUR, Miguel (2004). La démocratie contre l'État. Paris: Édition du Félin. AVINERI, Shlomo (1968). The social and political thought of Karl Marx. Cambridge: Cambridge University Press.

BALIBAR, Étienne (1995). A filosofia de Marx. Rio de Janeiro: Jorge Zahar. BERLIN, Isaiah (1991 [1978]). Karl Marx: sua vida, seu meio e sua obra. São Paulo: Siciliano.

BOBBIO, Norberto (1991 [1979]). "Existe uma doutrina marxista do Estado?", em O marxismo e o Estado. Rio de Janeiro: Graal.

CHÂTELET, François (1996 [1975]). O capital e outros estudos. Tradução de Edmundo Fernandes Dias. Campinas: Editora da Unicamp.

CLAUDIN, Fernando (1985). Marx, Engels y la Revolución de 1848. Madri: Siglo XXI.

DAYAN-HERZBRUN, Sonia (1990). Mythes et mémoire du mouvement ouvrier: le cas Ferdinand Lassalle. Paris: L'Harmattan.

DELLA VOLPE, Galvano (1974). Rousseau et Marx et autres écrits. Paris: Grasset.

DRAPER, Hal (1977). Karl Marx's theory of revolution. Volume I: State and bureaucracy. New York: Monthly Review Press. 
ENGELS, Friedrich (1886). "Discours de commémoration du quinzième anniversaire de la Commune de Paris". Disponível em: http://www. marxists.org/francais/marx/works/00/commune/kmfecom13.htm. Acessado em 22 jul. 2012.

HARDT, Michael \& NEGRI, Antonio (2004). O trabalho de Dioniso: para a crítica ao Estado pós-moderno. Juiz de Fora: UFJF.

HEGEL, Georg W. F. (1989 [1821]). Principes de la philosophie du droit. Paris: Gallimard,.

KOUVÉLAKIS, Stathis (2004). "Marx et sa critique de la politique". Comunicação no colóquio Sulle tracce di un fantasma: l’opera di Marx tra filologia e filosofía. Nápoles, Universidade Federico II, 1 a 3 de abril. Disponível em: http://www.preavis.org/breche-numerique/article1788. html. Acessado em 20 jan. 2014.

KRADER, Lawrence (1974). "Introduction”, em KRADER, Lawrence (ed.). The ethnological notebooks of Karl Marx: studies of Morgan, Phear, Maine, Lubbock. Assen: Van Gorcum.

LASCOUMES, Pierre \& ZANDER, Hartwig [1984a]. "Le droit, le bois, la vigne: éléments de contexte généraux", em Marx: $d u$ "vol de bois" à la critique du droit. Édition critique de "Débats sur la loi relative au vol de bois" et "Justification du correspondant de la Moselle". Paris: PUF.

[184b]. "Deux critiques centrales", em Marx: du "vol de bois" à la critique du droit. Édition critique de "Débats sur la loi relative au vol de bois" et "Justification du correspondant de la Moselle". Paris: PUF.

LÉNINE, Vladimir I. (1972 [1918]). L’Etat et la révolution: la doctrine marxiste de l'état et les tâches du prolétariat dans la révolution. Paris: Editions Sociales.

LÖWY, Michael (2002). A teoria da revolução no jovem Marx. Petrópolis: Vozes. (2009). "Politique", em DUMÉNIL, G.; LÖWY, Michael \& RENAULT, Emmanuel (coords.). Lire Marx. Paris: PUF. (2010). "Prefácio", em MARX, Karl. Lutas de classes na Alemanha. São Paulo: Boitempo.

MARX, Karl e ENGELS, Friedrich (2001 [1848]). Manifesto do Partido Comunista. São Paulo: Fundação Perseu Abramo. (2003 [1844]). A sagrada família. São Paulo: Boitempo. (2007 [1845-1846]). A ideologia alemã. São Paulo: Boitempo. (2010 [1850]). “Mensagem do Comitê Central à Liga [dos Comunis- 
tas]", em MARX, Karl. Lutas de classes na Alemanha. São Paulo, Boitempo. MARX, Karl. (1971a [1871]). "Lettre de Marx - 12 avril 1871", em MARX, Karl et. al.. Lettres à Kugelmann. Paris: Éditions Sociales. (1971b [1871]). "Lettre de Marx - 17 avril 1871", em MARX, Karl et. al.. Lettres à Kugelmann. Paris: Éditions Sociales.

(1971c [1871]). “The first draft", em MARX, Karl \& ENGELS, Friedrich. Writings on the Paris Commune. Organização de Hal Draper. Nova York: Monthly Review Press.

(1971d [1871]). "The Civil War in France", em MARX, Karl \& ENGELS, Friedrich. Writings on the Paris Commune. Organização de Hal Draper. Nova York: Monthly Review Press.

(1974a [1866]). "Provisional rules", em MARX, Karl. The First International and after. Political writings. Vol. 3. Organização de David Fernabach. Middlesex: Penguin.

(1974b [1866]). "Instructions for delegates to the Geneva Congress", em MARX, Karl. The First International and after. Political writings. Vol. 3. Organização de David Fernabach. Middlesex: Penguin.

(1974c [1867]). "Resolution of the London Conference on Working-class Political Action", em MARX, Karl. The First International and after. Political writings. Vol. 3. Organização de David Fernabach. Middlesex: Penguin.

(1982 [1842]) "Larticle de tête du numéro 179 de la 'Kölnische Zeitung"', em MARX, Karl. Oeuvres. Vol. 3. Organização de Marximilien Rubel. Paris: Gallimard, Bibliothèque de la Pléiade.

(1983). "The 'First' Draft" (1881), em SHANIN, Teodor (ed.). Late Marx and the Russian road: Marx and "the peripheries of capitalism". New York: Monthly Review Press.

(1984 [1842]). "Débats sur la loi relative au vol de bois", em LASCOUMES, Pierre \& ZANDER, Hartwig (coords.). Marx: $d u$ "vol de bois" à la critique du droit. Edição crítica de "Débats sur la loi relative au vol de bois" e "Justification du correspondant de la Moselle". Paris: PUF. (1997 [1852]). Le 18 brumaire de Louis Bonaparte. Paris: Mille et une Nuits. (2002a [1846]). “Lettre à Annenkov", em Misère de la philosophie. Paris: Payot. (2002b [1847]). Misère de la philosophie. Paris: Payot. 
(2002c [1850]). Les luttes de classes en France (1848-1850). Paris: Gallimard.

(2004 [1844]). Manuscritos econômico-filosóficos. São Paulo: Boitempo.

(2005a [1843]). Crítica da Filosofia do direito de Hegel. São Paulo: Boitempo.

São Paulo: Boitempo.

(2005b [1844]). Crítica da Filosofia do direito de Hegel - Introdução.

(2006a [1844]). Sur la question juive. Paris: La Fabrique.

(2006b [1867a]). Le capital. Livre Premier. Paris: PUF.

(2006c [1873]). "Postface à la deuxième édition allemande", em Le Capital. Paris: PUF.

(2007 [1845]). "Plano de trabalho sobre o Estado", em MARX, Karl \& ENGELS, Friedrich. A ideologia alemã. São Paulo: Boitempo.

(2009a [1857]). "Introduction générale", em Critique de l'économie politique. Philosophie. Edição organizada e anotada por Maximilien Rubel. Paris: Gallimard.

(2009b [1859]). "Preface", em Critique de l'économie politique. Philosophie. Edição organizada e anotada por Maximilien Rubel. Paris: Gallimard.

(2010a [1844]). “Glosas críticas ao artigo 'O rei da Prússia e a reforma social. De um prussiano”, em Lutas de classes na Alemanha. São Paulo: Boitempo.

(2010b [1894]). Le capital. Livros II e III. Paris: Folio.

MEZZADRA, Sandro (2008). La condizione postcoloniale: storia e politica nel presente globale. Verona: Ombre Corte.

NEGRI, Antonio (2002). O Poder Constituinte: ensaio sobre as alternativas da modernidade. Rio de Janeiro: DP\&A.

POGREBINSCHI, Thamy (2006). “Jovem Marx, nova teoria política”. DADOS - Revista de Ciências Sociais, v. 49, n. 3, p. 537-552.

(2009). O enigma do político. Rio de Janeiro: Civilização Brasileira. RUBEL, Maximilien (1974). Marx critique du marxisme. Paris: Payot. (1994). "Introduction". CEuvres IV - Politique I. Paris: Gallimard, Pléiade.

(2002). "Karl Marx devant le bonapartisme", em Les luttes de classes en France. Karl Marx. Paris: Gallimard. 
SAYER, Derek \& CORRIGAN, Philip (1987). "Revolution against the state: the context and significance of Marx's later writings". Dialectical Anthropology, n. 12, p. 65-82.

SEBAG, Lucien (1964). Marxisme et structuralisme. Paris: Payot.

\section{Resumo}

O que os textos de Marx, de seus artigos de 1842 até suas últimas reflexões, nos dizem sobre sua concepção da política? Existe um pensamento político marxiano? Se Marx não legou tratados de teoria política, insistiu em alguns pontos-chave, tais como a opressão estatal, sua articulação com a exploração capitalista e os elos entre revolução, democracia e comunismo. Isso pode ser percebido nos seus mais variados escritos, nas polêmicas com Hegel e os jovens hegelianos, nos textos sobre os levantes revolucionários (1848, Comuna de Paris), nos debates do movimento operário e nas obras sobre a economia política. Por isso, a proposta de seguir suas trajetórias nos numerosos e diferentes escritos (livros, artigos, cartas, comentários à margem), tomando como fio condutor o projeto marxiano de uma outra política no sentido da superação da sua dimensão estatal.

Palavras-chave: Karl Marx; estado; política; democracia.

\section{Abstract}

What do Marx's texts, from his 1842 articles to his last thoughts, tell us about his conception of politics? Is there a Marxian political thought? While Marx didn't bequeath a finished political theory, he insisted on some key points, such as state oppression, its articulation with capitalist exploitation and the links between revolution, democracy and communism. This can be seen in his various writings, in his controversies with Hegel and the Young Hegelians, in the texts on revolutionary upheavals (1848, The Paris Commune), in the debates within the labor movement and in works on political economy. Hence the proposal here to follow his trajectories in numerous and different writings (books, articles, letters, comments on the sidelines), taking as guiding thread the Marxian project of another politics towards overcoming its state dimension.

Keywords: Karl Marx; state; politics; democracy.

Recebido em 27 de julho de 2013.

Aprovado em 21 de dezembro de 2013. 